Original Article

\title{
ASSESSMENT OF KIDNEY FUNCTION, ESTIMATED GLOMERULAR FILTRATION RATE AND BODY MASS INDEX IN HIV SEROPOSITIVE SUBJECTS ON ANTIRETROVIRAL THERAPY IN NNEWI
}

\author{
EMMANUEL IKECHUKWU ONWUBUYA ${ }^{1}$, NKIRUKA ROSE UKIBE ${ }^{2 *}$, OFIA ANYA KALU ${ }^{1}$, SOLOMON NWABUEZE \\ UKIBE $^{3}$, IMO JOHN OBASI ${ }^{2}$
}

1Department of Internal Medicine, Faculty of Medicine, College of Health Sciences, Nnamdi Azikiwe University, Nnewi Campus, P. M. B 5025, Anambra State, Nigeria, ${ }^{2}$ Deparment of Medical Laboratory Science, College of Health Sciences, Nnamdi Azikiwe University, Nnewi Campus, P. M. B 5025, Anambra State, Nigeria, ${ }^{3}$ Department of Prosthesis and Orthotics, Federal University of Technology, Owerri, Imo State, Nigeria Email: nr.ukibe@unizik.edu.ng

Received: 14 May 2018 Revised and Accepted: 27 Jun 2018

\section{ABSTRACT}

Objective: Antiretroviral therapy (ART) is anticipated to result in an increase in long-term survival in human immunodeficiency virus (HIV) infected individuals, but may present with the development of associated complications including kidney damage. The present study aimed at assessing the kidney function estimated glomerular filtration (eGFR) rate and body mass index (BMI) of HIV seropositive subjects with or without HAART at Nnewi, Nigeria.

Methods: A total of 90 subjects were recruited comprising of 30 HIV-seropositive on highly antiretroviral therapy (HAART), 30 HIV-seropositive drug naive, and $30 \mathrm{HIV}$-seronegative (control subjects). Anthropometric parameters of the subjects were assessed using a well-structured questionnaire. Five millilitres of blood sample was collected from the patients and used for the estimation of urea, creatinine, uric acid, serum total protein and cluster of differentiation (CD4) T-cell counts using diacetyl monoxime method, Jaffe-slot method, Caraway phosphotungstic acid method, refractometry and flow cytometric method respectively.

Results: The result shows significantly higher mean serum urea, creatinine and uric acid levels in HIV seropositive drug-naive subjects and HIV seropositive subjects on HAART when compared with control $(\mathrm{p}<0.05)$. Similar observation were made with same parameters between HIV seropositive drug-naive subjects and HIV subjects on HAART $(\mathrm{p}<0.05)$. However, total protein and CD4 T-cells counts were significantly lower in HIV seropositive drug-naive subjects compared with HIV subjects on HAART and controls $(\mathrm{p}<0.05)$. Based on the chronic kidney disease epidemiology collaboration (CKD-EPI) equation, $6(20.0 \%)$ of HIV seropositive subjects on antiretroviral therapy had a mild renal impairment, while $2(6.6 \%)$ had a moderate renal impairment. Based on the modification of diet in renal disease (MDRD) equation, 7 (23.3\%) of HIV subjects on therapy had mild renal impairment while $2(6.6 \%)$ had a moderate renal impairment. Among the HIV drug naïve subjects, $8(26.7 \%)$ had mild renal impairment based on both equations. However, there were no significant differences in BMI and eGFR between HIV seropositive subjects on therapy and HIV seropositive drug-naive subjects.

Conclusion: The present study shows evidence of significant alterations in serum urea, creatinine, and uric acid levels with mild and moderate state of renal impairment in HIV infected subjects with or without therapy. The significantly lower CD4 count and serum total protein in HIV naive subjects compared with HIV on HAART and control indicates reduced cellular immunity. Routine kidney function test using longitudinal study and more sensitive predictors for renal damage are recommended to ascertain the clearer picture of renal disease burden among HIV subjects in this environment.

Keywords: Renal function, Estimated glomerular filtration rate, Body mass index, HIV HAART

(C) 2018 The Authors. Published by Innovare Academic Sciences Pvt Ltd. This is an open access article under the CC BY license (http://creativecommons.org/licenses/by/4.0/) DOI: http://dx.doi.org/10.22159/ijpps.2018v10i8.27291

\section{INTRODUCTION}

Human immunodeficiency virus infection has become a public health challenge in the modern world today [1]. About 36.7 million people were living with HIV at the end of 2015 globally [2] and the incidence of HIV in Nigeria is 3.2\% [3]. Infection with the HIV affects several body organs and systems, including the kidneys. The kidneys are the primary means for eliminating waste products of metabolism that are no longer needed by the body. These products include urea, creatinine, uric acid, bilirubin and metabolites of various hormones. These waste products must be eliminated from the body as rapidly as they are produced. Most toxins which are produced by the body or ingested and other foreign substances such as pesticides, drugs, and food additives are also eliminated through the kidneys [4].

The process of filtering these waste products from the blood and excreting them in the urine is one of the metabolic functions of the kidney and the rates at which these substances are excreted in the urine represent the sum of three renal processes which are glomerular filtration, reabsorption of substances from the renal tubules into the blood, and secretion of substances from the blood into the renal tubules [4].
Glomerular filtration rate (GFR) measures the rate at which substances are filtered from the blood into the urine. The development of formula-based calculation of eGFR has offered a very practical and easy approach for converting serum creatinine value into GFR result taking into consideration patient's age, sex, ethnicity and weight depending on equation type. The commonly used equations include Cockcroft and Gault (1976), MDRD (1999) and CKD-EPI (2009) [5]. Hence, cystatin C, blood urea, creatinine, uric acid and eGFR can be used to assess kidney functions. The blood levels of these substances are usually raised above the reference ranges as a result of impaired kidney functions [6]. Diabetes, high blood pressure, age, race, obesity, high cholesterol, lack of physical exercise, smoking, and excessive salt intake are factors that increase the risk of kidney disease. Other contributing circumstances include infections or inflammatory diseases that affect the kidney; inappropriate use of medications like aspirin, ibuprofen, and other painkillers [7]. Human immunodeficiency virus/Acquired immunodeficiency syndrome (HIV/AIDS) infection has also been known to cause renal disease in infected patients. Renal disease is also becoming more prevalent in HIV-infected patients. The renal impairment can present as acute or chronic kidney disease; it can be 
caused directly or indirectly by HIV and/or by drug-related effects that are directly nephrotoxic or lead to changes in renal function by inducing metabolic vasculopathy and renal damage [8]. Renal damage caused by HAART can result in a variety of toxic drug effects presenting as an acute renal failure, tubular necrosis, kidney stones, or chronic renal disease [8]. For example, long-term use of tenofovir disoproxil is associated with nephrotoxicity and bone loss. Presentation of nephrotoxicity can appear as Fanconi syndrome, acute kidney injury, or decline of GFR. Nephrotoxicity may be due to proximal tubules accumulation of tenofovir disoproxil leading to elevated serum concentrations [9]. Recent reports have linked HAART regimens that contain tenofovir to a mild, time-dependent elevation in the serum creatinine level and a decrease in the glomerular filtration rate [10]. Furthermore, a study has attributed the high prevalence of hyperuricemia seen in HIV-positive patients to the use of antiretroviral therapy such as a combination of didanosine and stavudine [11]. More so, an increase in the serum creatinine level frequently preceded by sterile leucocyturia, which normalized after its discontinuation, has been observed with indinavir treatment [8]. Ritonavir use has also been linked to reversible renal failure with an increase in the serum creatinine level [12]. However, the underlying mechanism behind nephrotoxicity in antiretroviral therapy is not fully understood. Since there is a correlation between the use of antiretroviral therapy in HIV/AIDS subjects and renal disease, the present study aims at assessing kidney function, estimated glomerular filtration rate and body mass index in HIV seropositive subjects with or without therapy at NAUTH, Nnewi, Nigeria.

\section{MATERIALS AND METHODS}

\section{Study design}

This was a cross-sectional study designed to assess kidney function, body mass index and estimated glomerular filtration rate in HIV seropositive subjects with or without HAART attending HIV outpatient clinic at Nnamdi Azikiwe University Teaching Hospital, Nnewi, Anambra State Nigeria. The study was carried out between June and August 2017. The study participants comprised of a total of 90 subjects aged 18-65 y, out of which 30 (Female $=21$, Male $=9$ ) were HIV seropositive subjects who had been receiving HAART for not less than least 6 mo, they were recruited at HIV clinic during their routine follow up at the clinic. 30 (Female $=18$, Male $=12$ ) were HIV seropositive drug-naive subjects who were recruited at Heart to Heart Centre at their initial visit while 30 (Female $=17$, Male $=13$ ) were HIV seronegative subjects regarded as a control group. They were apparently healthy individuals recruited among the hospital staff.

Five (5) ml of blood was collected aseptically by venepuncture with vacutainer needles and syringe and dispensed into ethylenediaminetetraacetic acid-anticoagulated containers for CD4+count. Also, another $5 \mathrm{ml}$ of blood was collected and dispensed into plain tubes, centrifuged at 5,000 rpm for $5 \mathrm{~min}$ and the serum separated and stored at $-20^{\circ} \mathrm{C}$ until assayed for urea, creatinine and uric acid. Other biodata were collected using a pre-tested interviewer-administered questionnaire.

The heights of the subjects were measured with a metre rule and their weights measured with a weighing scale. Their body mass index was then calculated by the formula described by Gadzik, [13] where BMI $=\frac{\operatorname{mass}(\boldsymbol{k g})}{\operatorname{height}(\boldsymbol{m})^{2}}$

\section{Inclusion and exclusion criteria}

Asymptomatic HIV subjects in stage 1, symptomatic HIV subjects in stage 2 and symptomatic HIV subjects in stage 2 on therapy, and HIV seronegative subjects (control group) within the age bracket of 18$65 \mathrm{y}$ were included in this study. HIV subjects in stages 3 and 4 were excluded from the study. Those on HAART for less than $6 \mathrm{mo}$, pregnant and lactating women, those with documented hypertension, diabetes and those with known dyslipidaemia before the commencement of the study were excluded. Individuals who are outside the age bracket of 18-65 y were excluded from this study.

\section{Antiretroviral drugs administration}

Participants on antiretroviral therapy were given either of the following regimens: a generic fixed-dose combination of zidovudine
(ZDV) $300 \mathrm{mg}$ twice daily orally+lamivudine (3TC) $150 \mathrm{mg}$ twice daily orally+nevirapine (NVP) $200 \mathrm{mg}$ twice daily orally. (Zidovudine and lamivudine are nucleoside reverse transcriptase inhibitors while nevirapine is a non-nucleoside reverse transcriptase inhibitor (NNRTI) or (2) Stavudine (D4T) $30 \mathrm{mg}$ twice daily orally+lamivudine (3TC) $150 \mathrm{mg}$ twice daily+nevirapine (NVP) $200 \mathrm{mg}$ twice orally. (Stavudine is also a nucleoside reverse transcriptase inhibitor).

\section{Ethical consideration and informed consent}

The ethical approval for this research was obtained from the Nnamdi Azikiwe University Teaching Hospital ethics committee with ref NAUTH/CS/66/Vol.10/25/2017/006 in accordance with the Helsinki declaration by the world medical association (WMA) on the ethical principles for medical research involving human subjects [14]. Informed consent was obtained from each of the participants.

\section{Methods}

\section{Determination of antibodies to HIV-1 and/or HIV-2}

HIV testing was performed using the national algorithm described by the World Health Organization [15]. The procedure involved serial testing by determine, uni-gold and stat-pak test kits.

\section{CD4+T-Cell count}

The Cluster of Differentiation count was performed by the method described by Greve, [16]. Principle: The mouse monoclonal antibody MEM-241 recognizes the human CD4 antigen, a transmembrane glycoprotein $(55 \mathrm{kD})$ of the immunoglobulin supergene family, present on a subset of lymphocytes ("helper/inducer" T-cells) and also expressed at a lower level on monocytes, tissue macrophages and granulocytes. The antigen-antibody reaction is quantitated using a partec flow cytometer which works on the principle of immunofluorescence.

\section{Estimation of urea}

Serum urea and creatinine estimation were performed by diacetyl monoxime and Jaffe-Slot methods respectively as described by Kaplan and Teng, [17]. Principle: Urea reacts with diacetyl monoxime under strongly acidic conditions in the presence of ferric ions and thiosemicarbazide to give a pink-coloured complex. Absorbance is read at $520 \mathrm{~nm}$ wavelength. While creatinine reacts with the picric acid in an alkaline medium to produce an orange-red complex. The rate of formation of colour is proportional to the creatinine concentration in the sample. Absorbance of the coloured complex is read at $510 \mathrm{~nm}$ wavelength using a spectrophotometer.

\section{Estimation of uric acid}

Uric acid was estimated by Caraway phosphotungstic acid method as described by Ingebretsen et al. [18]. Principle: Phosphotungstic acid oxidizes uric acid to allantoin. The reduction product of phosphotungstate in an alkaline medium is blue and is estimated by measuring absorbance at $700 \mathrm{~nm}$ wavelength.

\section{Determination of total protein by refractometry}

Principle: Refractometry is a rapid analytical method that is used to determine serum proteins when a very small volume of serum is needed. Total proteins are the major masses of the dissolved solids in blood plasma and are commonly measured by a hand-held refractometer. $50 \mu \mathrm{L}$ of serum was placed between a cover glass and the prism by capillary action. The refractometer was held so that light is refracted through the serum layer. The refracted rays caused part of the field of view to light, producing a point at which there is a sharp line between light and dark. The number of protein at this line on the internal scale will be read in $\mathrm{g} / \mathrm{dl}$

\section{Estimated glomerular filtration rate}

Estimated glomerular filtration rate was calculated using the modification of diet in renal disease (MDRD) equation as described by Levey et al. $[18,19]$ and chronic kidney disease epidemiology collaboration (CKD-EPI) equation as described by Levey et al. [20]. 


\section{The MDRD formula}

For creatinine in $\mu \mathrm{mol} / \mathrm{l}$ :

eGFR $(\mathrm{ml} / \mathrm{min} / 1.73 \mathrm{~m} 2)=32788 \times(\text { serum creatinine })^{-1.154} \times($ Age $)$ $0.203 \times[1.210$ if Black $] \times[0.742$ if female $]$.

For creatinine in $\mathrm{mg} / \mathrm{dl}$ :

eGFR $(\mathrm{ml} / \mathrm{min} / 1.73 \mathrm{~m} 2)=186 \times(\text { serum creatinine })^{-1.154 \times}(\text { Age })^{-}$ ${ }^{0203 \times} \times[1.210$ if Black $] \times[0.742$ female $]$.

\section{The CKD-EPI equation}

$\mathrm{eGFR}=141 \times \min (\mathrm{SCr} / \mathrm{k}, 1) \mathrm{a} \times \max (\mathrm{SCr} / \mathrm{k}, 1)^{-1.209} \times 0.993^{\text {Age }} \times$ [1.018 if female] $\times[1.159$ if Black]

Where $\mathrm{SCr}$ is serum creatinine $(\mathrm{mg} / \mathrm{dL})$, $\mathrm{k}$ is 0.7 for females and 0.9 for males, a is- 0.329 for females and-0.411 for males, min indicates the minimum of $\mathrm{SCr} / \mathrm{k}$ or 1 , and max indicates the maximum of $\mathrm{SCr} / \mathrm{k}$ or 1 .

As separate equations for different populations: For creatinine (IDMS calibrated) in $\mathrm{mg} / \mathrm{dL}$ :

Black female: If serum creatinine $(\mathrm{SCr})<=0.7$

$\mathrm{eGFR}=166 \times(\mathrm{SCr} / 0.7)^{-0.329 \times 0.993^{\text {Age }}}$

If serum creatinine $(\mathrm{SCr})>0.7$

$\mathrm{eGFR}=166 \times(\mathrm{SCr} / 0.7)^{-1} \cdot[20]^{9} \times 0.993^{\mathrm{Age}}$

Black male: If serum creatinine $(\mathrm{SCr})<=0.9$

$\mathrm{eGFR}=163 \times(\mathrm{SCr} / 0.9)^{-0.411 \times 0.993^{\text {Age }}}$

If serum creatinine $(\mathrm{SCr})>0.9$

$\mathrm{eGFR}=163 \times(\mathrm{SCr} / 0.9)^{-1.209} \times 0.993^{\text {Age }}$

\section{Statistical analysis}

The statistical analysis was performed using the independent students'-test and one-way ANOVA. Pearson correlation was used to determine the relationship between CD4 count and renal function parameters. Data were presented as mean \pm standard deviation (SD) and the level of significance was set at $\mathrm{p}<0.05$.

\section{RESULTS}

Levels of urea, creatinine, uric acid, BMI, esGFR and CD4 count in control subjects, HIV seropositive subjects on HAART and HIV seropositive drug-naive subjects (mean \pm SD)

Urea was significantly higher in HIV drug-naive subjects (4.42 \pm 1.57$)$ and HIV subjects on HAART $(3.77 \pm 1.00)$ when compared with control subjects $(3.55 \pm 0.89)(\mathrm{p}<0.05)$ and significantly higher in HIV drug-naive subjects $(4.42 \pm 1.57)$ compared with HIV subjects on ART $(3.77 \pm 1.00)(p<0.05)$. The mean value of creatinine was significantly higher in HIV drug-naive subjects $(89.4 \pm 29.14)$ and HIV subjects on HAART $(79.31 \pm 16.80)$ when compared with the value in control subjects $(75.83 \pm 24.87)(\mathrm{p}<0.05)$. A similar observation was made between HIV drug-naïve subjects $(89.4 \pm 29.14)$ and HIV subjects on HAART $(79.31 \pm 16.80)(\mathrm{p}<0.05)$.

The mean value of uric acid was significantly higher in HIV drugnaive subjects $(395.99 \pm 121.65)$ and HIV subjects on HAART $(324.03 \pm 120.16)$ when compared with the value in control subjects $(280.89 \pm 80.57)(\mathrm{p}<0.05)$. The same observation was made between HIV drug-naive subjects $(395.99 \pm 121.65)$ and HIV subjects on ART $(324.03 \pm 120.16)(\mathrm{p}<0.05)$.

The mean serum level of total protein was significantly lower in lower in both HIV subjects on HAART $(6.02 \pm 1.87)$ and HIV drugnaive subjects $(4.46 \pm 1.52)$ when compared with controls $(7.13 \pm 2.80)(p<0.05)$. Similarly, serum total protein was significantly lower in HIV drug naïve subjects $(4.46 \pm 1.52)$ when compared with the counterpart on HAART $(6.02 \pm 1.87)(\mathrm{p}<0.05)$

However, the mean CD4 T-cell count was significantly lower in HIV drug-naive subjects $(401.25 \pm 90.01)$ when compared with the value in HIV seropositive HIV subjects on ART $(655.00 \pm 121.65)$ and control subjects $(701.44 \pm 130.06)(\mathrm{p}<0.05$ respectively)(table 1$)$

Table 1: Levels of urea, creatinine, uric acid, CD4 count, BMI and eGFR in control, HIV seropositive on HAART and HIV seropositive drug naive subjects (mean $\pm \mathrm{SD}$ )

\begin{tabular}{|c|c|c|c|c|c|c|c|c|}
\hline Groups & $\begin{array}{l}\text { Urea } \\
(\mathrm{mmol} / \mathrm{l})\end{array}$ & $\begin{array}{l}\text { Creatinine } \\
(\mu \mathrm{mol} / \mathrm{l})\end{array}$ & $\begin{array}{l}\text { Uric acid } \\
(\mu \mathrm{mol} / \mathrm{l})\end{array}$ & $\begin{array}{l}\text { Total } \\
\text { protein } \\
(\mathrm{mg} / \mathrm{dl})\end{array}$ & $\begin{array}{l}\text { BMI } \\
\left(\mathrm{kg} / \mathrm{m}^{2}\right)\end{array}$ & $\begin{array}{l}\text { eGFR (ml/min) } \\
\text { (CKD-EPI) }\end{array}$ & $\begin{array}{l}\text { eGFR } \\
(\mathrm{ml} / \mathrm{min} / 1.73 \mathrm{~m} \\
\left.{ }^{2}\right)(\mathrm{MDRD})\end{array}$ & $\begin{array}{l}\text { CD4 count } \\
(\text { Cells } / \mu l)\end{array}$ \\
\hline $\begin{array}{l}\text { Control } \\
\text { (A). } n=30\end{array}$ & $3.55 \pm 0.89$ & $75.83 \pm 24.87$ & $280.89 \pm 80.57$ & $7.13 \pm 2.80$ & $24.31 \pm 3.59$ & $107.21 \pm 28.25$ & $103.40 \pm 27.83$ & $701.44 \pm 130.06$ \\
\hline $\begin{array}{l}\text { HIV on } \\
\text { HAART } \\
\text { (B). } n=30\end{array}$ & $3.77 \pm 1.00$ & $79.31 \pm 16.80$ & $\begin{array}{l}324.03 \pm 120.1 \\
6\end{array}$ & $6.02 \pm 1.87$ & $24.38 \pm 3.05$ & $110.60 \pm 27.25$ & $112.10 \pm 33.05$ & $655.00 \pm 121.65$ \\
\hline $\begin{array}{l}\text { HIV drug } \\
\text { naive (C). } \\
n=30\end{array}$ & $4.42 \pm 1.57$ & $89.40 \pm 29.14$ & $\begin{array}{l}395.99 \pm 121.6 \\
5\end{array}$ & $4.46 \pm 1.52$ & $23.13 \pm 2.85$ & $108.15 \pm 23.24$ & $108.94 \pm 30.98$ & $401.25 \pm 90.01$ \\
\hline f-value & 3.313 & 2.261 & 8.865 & 4.511 & 0.890 & 0.124 & 0.614 & 4.089 \\
\hline p-value & 0.042 & 0.011 & 0.001 & 0.003 & 0.415 & 0.884 & 0.544 & 0.045 \\
\hline A vs $B$ & 0.442 & 0.202 & 0.061 & 0.004 & 0.937 & 0.627 & 0.275 & 0.117 \\
\hline A vs $C$ & 0.013 & 0.018 & 0.006 & 0.000 & 0.243 & 0.911 & 0.561 & 0.000 \\
\hline B vs C & 0.030 & 0.041 & 0.032 & 0.000 & 0.218 & 0.769 & 0.740 & 0.002 \\
\hline
\end{tabular}

Data was expressed in mean $\pm S D$, level of significance was represented at $\mathrm{p}<0.05, \mathrm{n}=$ number of sample used per group of subjects $=30$.

\section{Comparison of renal function among study participants based on the CKD-EPI and MDRD equations}

Based on the CKD-EPI equation, $23(76.7 \%)$ in the control group had a normal renal function (e GFR $\geq 90 \mathrm{ml} / \mathrm{min}$ ) while 7 (23.3\%) had mild or moderate renal impairment. Among HIV subjects on ART, 22 (73.3\%) had a normal renal function (e GFR $90 \mathrm{ml} / \mathrm{min}$ ) while 8 (26.7\%) had mild or moderate renal impairment. Among HIV drugnaive subjects, $22(73.3 \%$ ) had a normal renal function (e GFR $\geq 90$ $\mathrm{ml} / \mathrm{min}$ ) while 8 (26.7\%) had a mild renal impairment.

Based on the MDRD equation, $24(80.0 \%)$ in the control group had a normal renal function (e GF\& $90 \mathrm{ml} / \mathrm{min}$ ) while 6 (20.0\%) had mild or moderate renal impairment. Among the HIV subjects on ART, $21(70.0 \%)$ had a normal renal function (e GER9 0 $\mathrm{ml} / \mathrm{min})$ while $9(30.0 \%)$ had mild or moderate renal impairment. In the Among HIV drug-naive subjects, 22 (73.3\%) had normal renal function (e GFE $90 \mathrm{ml} / \mathrm{min}$ ) while 8(26.7\%) had mild renal impairment.

$29(96.6 \%)$ of control participants had normal body mall index with $1(3.3 \%)$ overweight while in HIV seropositive subjects on HAART, $12(40.0 \%)$ were overweight while $1(3.3 \%)$ was underweight. In the HIV seropositive drug-naive subjects, 20 $(66.7 \%)$ had a normal mean body mass index while 10 (33.3\%) were overweight (table 2). 
Table 2: Comparison of body mass index, renal function among study participants (CKD-EPI and MDRD)

\begin{tabular}{|c|c|c|c|}
\hline Parameter & Control $(n=30)$ & HIV on HAART $(n=30)$ & HIV drug naive ( $n=30)$ \\
\hline \multicolumn{4}{|l|}{ CKD-EPI equation renal function } \\
\hline Normal (e GFR $\geq 90 \mathrm{ml} / \mathrm{min}$ ) & $23(76.7 \%)$ & $22(73.3 \%)$ & $22(73.3 .0 \%)$ \\
\hline Mild (e GFR 60-89 ml/min) & $5(16.7 \%)$ & $6(20.0 \%)$ & $8(26.7 \%)$ \\
\hline Moderate (e GFR $30-59 \mathrm{ml} / \mathrm{min}$ ) & $2(6.6 \%)$ & $2(6.6 \%)$ & None \\
\hline Severe (e GFR 15-29 ml/min) & None & None & None \\
\hline Renal failure $(\mathrm{e} G F R<15 \mathrm{ml} / \mathrm{min})$ & None & None & None \\
\hline \multicolumn{4}{|l|}{ MDRD equation } \\
\hline Normal (e GFR $\geq 90 \mathrm{ml} / \mathrm{min}$ ) & $24(80.0 \%)$ & $21(70.0 \%)$ & $22(73.3 \%)$ \\
\hline Mild (e GFR 60-89 $\mathrm{ml} / \mathrm{min}$ ) & $3(10.0 \%)$ & $7(23.3 \%)$ & $8(26.7 \%)$ \\
\hline Moderate (e GFR $30-59 \mathrm{ml} / \mathrm{min}$ ) & $3(10.0 \%)$ & $7(23.3 \%)$ & None \\
\hline Severe (e GFR 15-29 ml/min) & None & None & None \\
\hline Renal failure $(\mathrm{e} G F R<15 \mathrm{ml} / \mathrm{min}$ ) & None & None & None \\
\hline \multicolumn{4}{|l|}{ 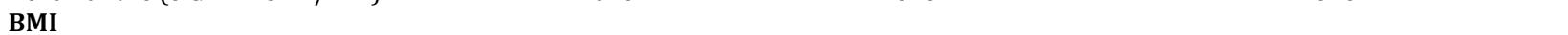 } \\
\hline Normal $\left(18.5-24.9 \mathrm{~kg} / \mathrm{m}^{2}\right)$ & $29(96.7 \%)$ & $17(56.6 \%)$ & $20(66.7 \%)$ \\
\hline Underweight $\left(<18.5 \mathrm{~kg} / \mathrm{m}^{2}\right)$ & 0 & $1(3.3 \%)$ & 0 \\
\hline Overweight $\left(25.0-29.9 \mathrm{~kg} / \mathrm{m}^{2}\right)$ & $1(3.3 \%)$ & $12(40.0 \%)$ & $10(33.3 \%)$ \\
\hline
\end{tabular}

CKD-EPI=Chronic kidney disease epidemiology collaboration. MDRD= Modification of diet in renal disease. eGFR= estimated glomerular filtration rate. $n=$ number of sample used.

\section{DISCUSSION}

In the present study, urea was significantly higher in HIV drug-naive subjects and HIV subjects on HAART when compared with control subjects and significantly higher in HIV drug-naive subjects when compared with HIV subjects on HAART. This is in agreement with previous reports $[21,22]$. The increased urea level in HIV infected subjects (though within the reference range) is an indication of future prerenal uremia and impaired kidney functions. This can be attributed to high protein intake, muscle wasting, nutrition or dehydration which is prevalent in HIV infection. It may also be as result of catabolism or excess production of urea in the affected individuals. Similar observations were made in the values of serum creatinine and uric acid level when compared in the same groups of subjects. This is consistent with the report of Reddy and Prasad [23]. Elevated creatinine levels in HIV subjects have also been reported in other studies [24-26]. The kidneys excrete a variety of waste products produced by metabolism into the urine. These include the nitrogenous wastes urea, from protein catabolism, uric acid from nucleic acid metabolism, and creatinine from muscle creatine [4]. HIV/AIDS infection has also been known to cause renal disease in infected patients. Studies have shown that there is significant renal impairment among HIV-infected patients who are naive to HAART [21]. In a recent study, a prospective analysis of 754 HIV-infected patients reported an incidence of $5.9 \%$ [27]. In Ghana, it has been established that there is renal dysfunction among both patients on HAART and those yet to start HAART, and it was suggested that there is need for dose adjustments, especially before onset of therapy [28]. At all stages of HIV infection, renal disorders may be evident, ranging from fluid and electrolyte imbalances to end-stage renal disease (ESRD). Loss of kidney function may be attributable to treatment-related factors, intermittent viraemia, and traditional risk factors for kidney disease [29]. Renal damage caused by antiretroviral drugs can result in a variety of toxic drug effects presenting as acute renal failure, tubular necrosis, kidney stones, or chronic renal disease [8]. Renal dysfunction may, therefore, be a common finding in patients infected with HIV, and necessitates increased surveillance and adaptation of dosages of HIV drugs [8]. Knowledge on the renal function status of such individuals from time to time, will improve management strategies [30].

Hyperuricemia is multifactorial in origin in HIV patients. Elevated uric acid level observed in the present study has been attributed to increased cell turnover [31, 32]. Reports have implicated increased uric acid levels to HIV infection itself and alteration in the HAART regimen such as didanosine or stavudine or both combinations [33]. The author attributed the association between dideoxynucleoside analogues (Stavudine and didanosine) and elevated urate to respiratory chain failure which causes ATP depletion thereby increasing urate production in the purine nucleotide cycle. This leads to mitochondria dysfunction and increased lactate which competes with urate for tubular excretion in the kidney. Other reports have also shown that hyperuricemia in HIV infection could result from low CD4 T-Cell, co-infection with either hepatitis B or C virus and other immunological and pathological conditions that characterize HIV disease progression [11].

The study observed significantly lower serum total protein in both HIV drug-naive subjects and HIV subjects on HAART when compared with controls. This is consistent with previous reports $[34,35]$. However, another study by Audu et al. [36] reported higher levels of total protein in HIV patients. Reports have shown that reduction in serum total protein in HIV infection may be due to increased losses and/or catabolism, malabsorption, fatigue, fever, depression and adverse drug effects [36].

In the present study, $12(40.0 \%)$ of HIV seropositive subjects on antiretroviral therapy were overweight, 1(3.3\%) were underweight while 17 (56.6\%) had a normal mean body mass index. This contrasts the observation in control subjects where $29(96.6 \%)$ had normal body mass index with $1(3.3 \%)$ overweight. This is similar to the findings of Carolline et al. [37] who reported the prevalence rate of $32.1 \%$ overweight and $8.8 \%$ underweight in HIV seropositive subjects on therapy. In the HIV seropositive drug naïve subjects, 20 $(66.7 \%)$ had normal mean body mass index while $10(33.3 \%)$ were overweight. The prevalence of overweight among HIV drug naïve subjects in this study (33.3\%) is comparable to the findings of Anyabolu [38] who reported $38.4 \%$ overweight in newly diagnosed HIV subjects. Studies on BMI in HIV subjects have shown an increasing prevalence of overweight and obesity more than underweight $[39,40]$. Seroconversion, changes in metabolism and co-morbidities in the early phases of HIV infection have been shown to influence weight in these subjects [41, 42]. The nutritional changes experienced by individuals living with HIV/AIDS seem to be related both to the recent use of HAART and to the dietary patterns and habits of each population [43]. Although antiretroviral therapy has influenced the pattern of weight changes in HIV subjects, factors associated with underweight, or overweight/obesity in drug-naive individuals with HIV infection, are not completely known [39].

The present study observed no significant difference in eGFR between HIV seropositive subjects on therapy and HIV seropositive drug-naive subjects with mild and moderate incidence of renal impairment. Studies have shown that HAART reduces the progression of HIV to AIDS and prevents the development of HIV induced ESRD [44]. Some reports have also shown that HAART is associated with decreased prevalence of renal disease and amelioration of progression in the general population and in HIV infected patients with chronic renal disease [45-47]. Some degrees of adverse drug reactions have been reported after the use of HAART in HIV infected subjects including the use of second-line regimen [48] However, studies have reported cases of kidney disease after the introduction of tenofovir-containing HAART $[9,49]$. 
Other drugs (Indinavir, efavirenz and keletra) have also been incriminated as the cause of kidney disease in HIV positive individuals. All these drugs are used in cases of proven toxicity with other drugs. On the other hand, it has been noted previously that HIV/AIDS develops more rapidly in infected patients in blacks, playing a very crucial role in the low prevalence as well as delaying the development of renal disease before death of the patients [50, 51]. However, our study subjects did not use any of these combinations and there was no adverse reaction reported by the subjects at the time of the study. The reduction in renal damage in the present study may be attributed to absence of adverse drug reactions observed during the course of the study. It may be due to increased CD4 T-cell counts above $250 / \mu \mathrm{l}$ recorded in these subjects. A further longitudinal study using more sensitive predictors of renal damage in HIV infected individuals with or without therapy is strictly recommended in the study area. This would throw more light on identifying the pattern of renal disease and possible genetic as well as environmental factors associated with kidney disease in this environment.

In this study, there was an increase in the mean CD4+T-cell count in HIV seropositive subjects on HAART and control subjects when compared with that of HIV seropositive drug-naive subjects. This finding is still consistent with our previous reports [52, 53]. Obirikorang et al. [54] however, observed an increase in mean CD4 count in HIV seropositive naïve subjects when compared with HIV seropositive subjects on HAART. Low CD 4 count $<200$ cells $/ \mu$ l has been implicated with kidney disease $[55,56]$. Contrastingly, several researchers reported increased $\mathrm{CD} 4+\mathrm{T}$-cell count as a high-risk factor for developing renal toxicity $[49,57-59]$.

\section{CONCLUSION}

The present study showed evidence of mild and moderate changes in renal function in HIV infected subjects with or without therapy. This suggests the role of HIV infection, antiretroviral therapy and the presence of other traditional risk factors prior to the infection. Assessment of kidney function in HIV seropositive subjects before and during antiretroviral therapy is recommended. This is to aid in the selection of drug combinations and dose adjustments to achieve the desired therapeutic effects while minimizing the risk of drug adverse effects. More so, it is recommended that further research be carried out to elucidate the mechanisms underlying variations in kidney function and disease progression among HIV seropositive subjects on and off antiretroviral therapy.

\section{ACKNOWLEDGEMENT}

We are immensely grateful to all the HIV/AIDS patients attending Heart to Heart centre and HIV clinic at Nnamdi Azikiwe University Teaching Hospital, Nnewi, Anambra State, Nigeria, for given us their informed consent to use their sample for analysis.

\section{AUTHORS CONTRIBUTIONS}

1. Conceptualization and study design-Nkiruka Rose Ukibe, Solomon Nwabueze Ukibe.

2. Data collection, sample analysis and performing the experimentNkiruka Rose Ukibe, Emmanuel Ikechukwu Onwubuya, Ofia Anya Kalu, Imo Obasi Kalu.

3. Preparation of manuscript-Nkiruka Rose Ukibe, Solomon Nwabueze Ukibe,

\section{Statistical Analysis-Ofia Anya Kalu, Emmanuel Ikechukwu}

5. Proofreading the manuscript-Solomon Nwabueze Ukibe, Emmanuel Ikechukwu

6. All authors read and approved the final manuscript.

\section{CONFLICT OF INTERESTS}

All authors have none to declare

\section{LIMITATION OF STUDY}

The sample size was limited due to inability of some of the HIV infected subjects given their informed consent during sample collection. Also the study was self-sponsored and experienced some difficulty in procuring some sensitive predictors of renal failure such as cystatin $\mathrm{C}$ which would have help in proper categorization of HIV infected subjects with clear picture of renal impairment.

\section{REFERENCES}

1. Arindam P, Maitreyee B, Shantasil P, Biswadip G, Sandip S Anirban G. Anaemia in antiretroviral naive HIV/AIDS patients: a study from Eastern India. J Health Allied Sci 2011;10:973-97.

2. World Health Organization. Global Human Immunodeficiency Virus Report; 2015. Available from: www.who.int/gho/hiv/en. [Last accessed on 10 Feb 2017]

3. The Joint United Nations Programme on HIV/AIDS. HIV and AIDS Estimates; 2015. Available from: www.unaids.org/en/ regionscountries/countries/nigeria.pdf. [Last accessed on 08 Feb 2017]

4. Guyton AC, Hall JE. Textbook of medical physiology. 12th ed. Philadelphia: Elsevier; 2011. p. 303-5.

5. Waad AS, Mula-Abed KR, Dawood AR. Estimated glomerular filtration rate (eGFR): a serum creatinine-based test for the detection of chronic kidney disease and its impact on clinical practice. Oman Med J 2012;27:108-13.

6. Irfanullah K, Amer HK, Azreen SA, Amjad K. Serum cystatin c role in the identification of renal dysfunction among elderly CKD patients. Asian J Pharm Clin Res 2016;9:2.

7. Aria AR. Chronic Kidney Disease. JAMA 2016;315:2248.

8. Röling J, Schmid H, Fischereder M, Draenert R, Goebel FD. HIVassociated renal diseases and highly active antiretroviral therapy-induced nephropathy. Clin Infect Dis 2006;42:1488-95.

9. Ustianowski A, Arends JE. Tenofovir: what we have learnt after 7.5 million person-years of use. Infect Dis Ther 2015;4:145-57.

10. Antoniou T, Raboud J, Chirhin S, Yoong D, Govan V, Gough K, et al. Incidence of and risk factors for tenofovir-induced nephrotoxicity: a retrospective cohort study. HIV Med 2005;6:284-90.

11. Walker UA, Hoffmann C, Enters M, Thoden J, Behrens G, Mitzel SL. High serum urate in HIV-infected persons: the choice of the antiretroviral drug matters AIDS 2006;20:1556-8.

12. Bochet MV, Jacquiaud C, Valantin MA, Katlama C, Deray G. Renal insufficiency induced by ritonavir in HIV-infected patients. Am J Med 1998;105:457.

13. Gadzik J. How much should I weigh?"--Quetelet's equation, upper weight limits, and BMI prime. Conn Med 2006;70:81-8.

14. World Medical Association. Declaration of Helsinki: Ethical Principles for Medical Research Involving Human Subjects. J Am Med Assoc 2018;310:2191-4.

15. World Health Organization. Antiretroviral therapy for HIV infection in adults and adolescents: recommendations for a public health approach; 2010. p.19-20. Available from: http://whqlibdoc.who.int/publications/2010/978924159976 4_eng.pdf [Last accessed on 28 Jun 2017]

16. Frylanda $\mathrm{M}$, Chaillet $\mathrm{P}$, Zachariahc R, Barnaba A, Bontee L, Andereassena $\mathrm{R}$, et al. The partec CyFlow Counter $\AA$ could provide an option for CD4+T-cell monitoring in the context of scaling-up antiretroviral treatment at the district level in Malawi. Transact Royal Soc Trop Med Hyg 2006;100:980-5.

17. Kaplan A, Teng LL. Urea in serum, urease-bertholet method. Sel Methods Clin Chem 1982;9:357.

18. Ingebretsen OC, Borgen J, Farstad M. Uric acid determinations: reversed-phase liquid chromatography. Diabet Care 2005;28:16476.

19. Levey AS, Bosch JP, Lewis JB, Greene T, Rogers N, Roth D. A more accurate method to estimate glomerular filtration rate from serum creatinine: a new prediction equation. Modification of Diet in Renal Disease Study Group. Ann Int Med 1999;130:461-70.

20. Levey AS, Stevens LA, Schmid CH, Zhang YL, Castro AF, Feldman HI, et al. CKD-EPI (Chronic Kidney Disease Epidemiology Collaboration) 2009;151:892-3.

21. Onodugo OD, Chukwuka C, Onyedum C, Ejim E, Mbah A. Baseline renal function among antiretroviral therapy-naive, HIV-infected patients in South East Nigeria. J Int Assoc Providers AIDS Care 2013;13:746-80.

22. Eneyew K, Seifu D, Menon M. Assessment of renal function among HIV-infected patients on combination antiretroviral 
therapy at tikur anbessa specialized hospital, addis ababa, ethiopia. Tech Invest 2016;7:107-22.

23. Reddy A, Prasad R. Renal function in antiretroviral treatment (ART) naive HIV positive patients in a tertiary care centre, South India. HIV Curr Res 2016;1:112.

24. Andia I, Pepper L, Matthieson P. Prevalence of renal disease in outpatients with HIV/AIDS in Mbarara Hospital. The 3rd International AIDS Society Conference on HIV Pathogenesis and Treatment, Rio de Janeiro; 2005. p. 24-7.

25. Emem CP, Arogundade F, Sanusi A, Adelusola K, Wokoma F, Akinsola A. Renal disease in HIV-seropositive patients in Nigeria: An assessment of prevalence, clinical features and risk factors. Nephrol Dial Transplant 2008;23:741-6.

26. Emejulu A, Onwuliri V, Ojiako O. Electrolyte abnormalities and renal impairment in asymptomatic HIV-infected patients in owerri, South Eastern Nigeria.Australian J Basic Appl Sci 2011;5:257-60.

27. Franceschini N, Napravnik S, Eron JJ, Szczech LA, Finn WF. Incidence and aetiology of acute renal failure among ambulatory HIV-infected patients. Kidney Int 2005;67:1526-31.

28. Owiredu WK, Quaye BA, Amidu L, Addai-Mensah A. Renal insufficiency in Ghanaian HIV infected patients: need for dose adjustment. Afr Health Sci 2013;13:101-11.

29. Okuonghae PO, Olisekodiaka MJ, Onuegbu J, Amara AG, Aberare LO. Evaluation of renal function in HIV patients on antiretroviral therapy. Adv Lab Med Int 2011;1:25-31.

30. Obirikorang C, Osakunor DNM, Ntaadu B, Adarkwa OK. Renal function in ghanaian HIV-infected patients on highly active antiretroviral therapy: a case-control study. PLoS One 2014;9:e99469.

31. Manfredi R, Mastroianni A, Coronado OV, Chiodo F. Hyperuricemia and progression of HIV disease. J Acquir Immune Defic Syndr Hum Retrovirol 1996;12:318-9.

32. Manfredi R, Chiodo F. Longitudinal assessment of serum urate levels as a marker of HIV disease progression. Int J STD AIDS 1998;9:433-4.

33. Lambert JS, Seidlin M, Reichman RC, Plank CS, Laverty M, Morse GD, et al. 20 $\mathrm{CE}, 3$ [aE-dideoxyinosine (ddI) in patients with the acquired immunodeficiency syndrome or AIDS-related complex. A phase I trial. N Engl J Med 1990;322:1333-40.

34. Ogundahunsi O, Akinyele OV, Ambali A, Mbacham W. The prevalence of renal disorder in HIV/AIDS patients on HAART. Int J Biomed Health Sci 2008;4:1-4.

35. Ukibe NR, Onyenekwe CC, Ahaneku JE, Ukibe SN, Meludu SC, Emelumadu FO. Evaluation of nutritional status of HIV infected females during menstrual cycle in Nnewi, Anambra state, Nigeria. Sci J Med Sci 2013;2:9.

36. Audu I, Agwale S, Tanimoto L, Womack C, Odama L, Leung K. Prevalence of HCV coinfection in HIV-infected individuals in nigeria and characterization of HCV genotypes. J Clin Virol 2004;31:S3-6.

37. Carolline AM, Maria FP, de Albuquerque M, de Alencar RA, de Melo HRL, Bandeira F. Body mass index in individuals with HIV infection and factors associated with thinness and overweight/obesity. Cadernos De Saúde Pública 2011;27:1997-2008.

38. Anyabolu EN. BMI and risk factors of underweight and obesity in HIV subjects in Eastern Nigeria. World J AIDS 2011;6:8-15.

39. Madeddu G, Spanu A, Solinas P, Calia GM, Lovigu C, Chessa F. Bone mass loss and vitamin D metabolism impairment in HIV patients receiving highly active antiretroviral therapy. Quarterly J Nuclear Med Mol Imaging 2004;48:39-48.

40. Hendricks KM, Mwamburi DM, Newby PK, Wanke CA. Dietary patterns and health and nutrition outcomes in men living with HIV infection. Am J Clin Nutr 2008;88:1584-92.

41. American Dietetics Association. Position of the American Dietetic Association and Dietitians of Canada: Nutrition
Intervention in the Care of Persons with Human Immunodeficiency Virus Infection. J Am Dietetic Assoc 2004;104:1425-41.

42. Dutra CDT, Libonati MF. Abordagemmetabólica e nutricional da lipodistrofiaemuso da terapia anti-retroviral. Rev Nutr 2008;21:239-46.

43. Johnson GP, Castrillon FJD, Ospina S. Alteraciones nutricionales en adultos infectados por el virus de la inmunodeficiencia humana. Perspectivas en Nutricion Humana 2004;12:23-37.

44. Schwartz EJ, Szczech LA, Ross MJ, Klotman ME, Winston JA, Klotman PE. Highly active antiretroviral therapy and the epidemic of HIV+End-stage renal disease. J Am Soc Nephrol 2005;16:2412-20.

45. Szczech LA, Gange SJ, Van-Der-Horst C, Bartlett JA, Young M, Cohen MH. Predictors of proteinuria and renal failure among women with HIV infection. Kidney Int 2002;61:195-202.

46. Kimmel PL. Pathogenesis and treatment of HIV-associated renal disease: lessons from clinical and animal studies, molecular pathologic correlations, and genetic investigations. Ann Int Med 2003;139:214-26.

47. Rao TK. Clinical features of human immunodeficiency virus 1991: Ray P, Lian X, Rakusanand T, Xue-Hui L. Nephrol, SectionSL45; 2004.

48. Pokala N, Dixit R, Manuhhai PM, Vijayala K. Adverse drug reactions with the second-line antiretroviral drug regimen. Asian J Pharm Clin Res 2014;7:75-9.

49. Kanai E, Hanabusa H. Renal tubular toxicity associated with tenofovir assessed using urine-beta 2 microglobulin alkaline phosphatase levels. AIDS 2005;19:203-3.

50. Cantor ES, Kimmel PL, Bosch JP. Effect of race on expression of acquired immunodeficiency-associated nephropathy. Arch Iran Med 1991;151:125-8.

51. Rao TK. Clinical features of human immunodeficiency virus associated nephropathy. Kidney Int 1991;40:S13-S18.

52. Pepper L, Andia I, Matthieson P. Prevalence of renal disease in patients attending the HIV/AIDS clinic at Mbarara University Teaching Hospital. Third International AIDS Society Conference on HIV Pathogenesis and Treatment, Rio de Janeiro, abstract TuPe15.3C02; 2004.

53. Ifeanyichukwu M, Onyenekwe CC, Elee PU, Ukibe NK, Meludu $\mathrm{SC}$, Ezechukwu CC, et al. Evaluation of CD4 T-cell count, interleukin 6(IL-6) and interferon gamma in HIV infected symptomatic and asymptomatic individuals. J Biomed Invest 2007;5:70-3.

54. Ukibe NR, Onyenekwe CC, Ahaneku JE, Meludu SC, Ukibe SN, Ilika A, et al. CD4+T-cells count in HIV-malaria co-infection in adult population in Nnewi, South Eastern Nigeria. Int J Biol Chem Sci 2010;4:1593-601.

55. Afhami S. Renal disorders in HIV-infected patients. Arch Iran Med 2007;10:335-8.

56. Kamga HLF, Assob JCN, Njunda AL, Nde FP, Nsagha DS, Atanga MBS, et al. The kidney function trends in human immunodeficiency virus/acquired immune deficiency syndrome (HIV/AIDS) patients at the Nylon District Hospital, Douala, Cameroon. J AIDS HIV Res 2011;3:30-7.

57. Coca S, Perazella MA. Rapid communication: acute renal failure associated with tenofovir: evidence of drug-induced nephrotoxicity. Am J Med Sci 2002;324:342-4.

58. Peyrière H, Reynes J, Rouanet I, Daniel N, de Boever CM, Mauboussin JM, et al. Renal tubular dysfunction associated with tenofovir therapy: report of 7 cases. J Acquired Immune Defic Syndr 2004;35:269-73.

59. Bhatnagar S, Sharma H, Sharma VK. Study of adverse effects of anti-retroviral therapy in HIV naïve patients and their association with cd4 cell count. Asian J Pharm Clin Res 2013;6:122-3. 